Brazilian Journal
of Chemical
Engineering

\title{
METHANOGENIC POTENTIAL AND MICROBIAL COMMUNITY OF ANAEROBIC BATCH REACTORS AT DIFFERENT METHYLAMINE/SULFATE RATIOS
}

\author{
D. V. Vich ${ }^{1 *}$, M. L. Garcia ${ }^{2}$ and M. B. A. Varesche ${ }^{1}$ \\ ${ }^{1}$ Laboratório de Processos Biológicos, (LPB), Departamento de Hidráulica e Saneamento, Escola de Engenharia de São Carlos, (EESC), \\ Phone: + (55) (16) 3373-8358, Fax: + (55) (16) 3373-9550, Universidade de São Paulo, (USP), Engenharia Ambiental-Bloco 4-F, \\ Av. João Dagnone 1100, Santa Angelina, CEP: 13.563-120, C. P. 359, São Carlos - SP, Brasil. \\ E-mail: varesche@sc.usp.br, ${ }^{*}$ danielevich@gmail.com \\ ${ }^{2}$ Departamento de Petrologia e Metalogenia, Universidade Estadual Paulista Julio de Mesquita Filho, (UNESP), \\ Phone: + (55) (19) 3526-2829, Avenida 24-A, 1515, Bela Vista, CEP: 13506-900, C. P. 178, Rio Claro - SP, Brasil. \\ E-mail: mlgarcia@rc.unesp.br
}

(Submitted: April 9, 2010 ; Revised: June 13, 2010 ; Accepted: June 29, 2010)

\begin{abstract}
Methylamine and sulfate are compounds commonly found in wastewaters. This study aimed to determine the methanogenic potential of anaerobic reactors containing these compounds and to correlate it with their microbial communities. Batch experiments were performed at different methylamine/sulfate ratios of $0.71,1.26$ and 2.18 (with respect to mass concentration). Control and experimental runs were inoculated with fragmented granular sludge. The maximum specific methane formation rates were approximately $2.3 \mathrm{mmol} \mathrm{CH}_{4} \mathrm{~L}^{-1} \mathrm{~g} \mathrm{TVS}^{-1} \mathrm{day}^{-1}$ for all conditions containing methylamine, regardless of sulfate addition. At the end of the experiment, total ammonium- $\mathrm{N}$ and methane formation were proportional to the initial concentrations of methylamine. In the presence of methylamine and sulfate, Firmicutes (46\%), Deferribacteres (13\%) and Proteobacteria (12\%) were the predominant phyla of the Bacteria domain, while Spirochaetes (40\%), Deferribacteres (17\%) and Bacteroidetes (16\%) predominated in the presence of methylamine only. There was no competition for methylamine between sulfate-reducing bacteria and methanogenic archaea.
\end{abstract}

Keywords: Anaerobic process; Methylamine; Sulfate reduction; Methane formation; Microbial community.

\section{INTRODUCTION}

Methylamine is an organic compound with a molecular weight of 31.1 g.mol ${ }^{-1}$, boiling point of $6,32^{\circ} \mathrm{C}(760 \mathrm{mmHg})$ and characteristic unpleasant odor at concentrations up to $100 \mathrm{ppm}$. It is introduced into the environment through several industrialized processes. It is mainly used as an intermediate in organic synthesis, water gel explosives, accelerators, pharmaceuticals, insecticides, herbicides, plasticizers, N-methylpyrrolidine, methylalkanolamines, surface active agents, and fungicides; in tanning; as a component of photographic developers and paint removers; as a fuel additive; in the production of dyes; as a polymerization inhibitor; and as a rocket propellant (Yaws, 2001). Complex methylaminederived organic molecules and others such as animal proteins can be broken down biologically to give methylamine as an end product, either by aerobic microorganisms in the presence of external electron acceptors or mainly by anaerobic microorganisms (Thauer, 1998). Hence, methylamine is a key

*To whom correspondence should be addressed

This is an extended version of the manuscript presented at the SINAFERM 2009 - 17th National Symposium on Bioprocesses 2009 , Natal, Brazil. 
compound to be studied, representing a variety of chemical classes.

Methanogenesis from methylamine yields carbon dioxide $\left(\mathrm{CO}_{2}\right)$, methane $\left(\mathrm{CH}_{4}\right)$ and ammonia $\left(\mathrm{NH}_{3}\right)$. In pure cultures, the ratio of product formation is $1: 3$ for $\mathrm{CO}_{2}$ and $\mathrm{CH}_{4}$, respectively, as indicated by reaction 1 . Unionized free ammonia is also produced in the conversion of methylamine to methane (Sossa et al., 2004), which can be an important element when representing mass balances of the anaerobic process.

$4 \mathrm{CH}_{3} \mathrm{NH}_{2}+2 \mathrm{H}_{2} \mathrm{O} \rightarrow 3 \mathrm{CH}_{4}+1 \mathrm{CO}_{2}+4 \mathrm{NH}_{3}$ (Reaction 1)

Methylotrophy, the metabolism of microorganisms that consume organic compounds containing no carbon-carbon bonds (C1 compounds), such as methane, methanol and methylated amines, is an important part of the global carbon cycle on Earth (Kalyuzhnaya et al., 2008). With respect to the Bacteria domain, methylotrophic ability is especially widespread within the Proteobacteria phylum, encompassing the alpha, beta and gamma subdivisions (Hanson and Hanson, 1996, Kalyuzhnaya et al., 2006). Within the methanogenic archaea, the order Methanosarcinales contains species with the most versatile substrate spectrum, including microorganisms that are able to grow on methylotrophic substrates such as methanol or methylamines as their sole carbon and energy sources (Deppenmeier et al., 1999).

To our knowledge, there are few studies of methylamine removal through biological processes. Because methylamine removal efficiencies can be extremely high and energy recovery can be practiced, anaerobic digestion can be an advantageous alternative. The process stability might be negatively affected in the presence of sulfate, which is often found in wastewaters. This work aimed to determine the influence of sulfate at different concentrations on the specific methane production rate and the microbial community structure of anaerobic batch reactors containing methylamine.

\section{MATERIALS AND METHODS}

Granular sludge from an Upflow Anaerobic Sludge Blanket (UASB) reactor treating poultry wastes (Dacar, Tietê, SP, Brazil) was used as an inoculum in batch reactors containing $\left[\mathrm{mg} \mathrm{L}^{-1}\right]$ : $\mathrm{NH}_{4} \mathrm{Cl}$ [500], $\mathrm{MgCl}_{2} 6 \mathrm{H}_{2} \mathrm{O}$ [400], $\mathrm{KH}_{2} \mathrm{PO}_{4}$ [100], $\mathrm{CaCl}_{2} \cdot 2 \mathrm{H}_{2} \mathrm{O}$ [50], Tritriplex [45], $\mathrm{FeSO}_{4} \cdot 7 \mathrm{H}_{2} \mathrm{O}$ [5.56], $\mathrm{MnSO}_{4} \cdot \mathrm{H}_{2} \mathrm{O} \quad[0.86], \quad \mathrm{CoCl}_{2} \cdot 6 \mathrm{H}_{2} \mathrm{O}$ [1.7], $\mathrm{ZnSO}_{4} \cdot 7 \mathrm{H}_{2} \mathrm{O}$ [2.1], $\mathrm{H}_{3} \mathrm{BO}_{3}$ [1.9], $\mathrm{NiCl}_{2}$ [0.2],
$\mathrm{Na}_{2} \mathrm{MoO}_{4}$ [0.1], $\mathrm{NaHCO}_{3}$ [1000], biotin [0.02], folic acid [0.02], thiamine $\mathrm{HCl}$ [0.05], riboflavin [0.05], niacin [0.05], calcium pantothenate [0.05], pyridoxine $\mathrm{HCl}$ [0.1], vitamin $\mathrm{B}_{12}$ [0.001], $\mathrm{Na}_{2} \mathrm{~S} \cdot 9 \mathrm{H}_{2} \mathrm{O}$ [500] and methylamine [1550] (Touzel and Albagnac, 1983; Zinder et al., 1984). The reactors were mounted in $2000 \mathrm{~mL}$ bottles, with $1000 \mathrm{~mL}$ of reaction volume and $1000 \mathrm{~mL}$ of headspace, which was initially filled with helium gas (He, 100\%). The experiments were performed in triplicate. Control conditions were set up as follows: I. no sulfate and no methylamine; II. no methylamine and sulfate addition; III. no sulfate and methylamine addition. Methylamine/sulfate experiments (IV) were designed with the following mass concentration ratios: 0.71 (a), 1.26 (b) and 2.18 (c) (Table 1).

Table 1: Methylamine and sulfate concentrations added to the anaerobic batch reactors.

\begin{tabular}{|c|c|c|}
\hline $\begin{array}{c}\text { Experimental } \\
\text { condition }\end{array}$ & $\begin{array}{c}\mathbf{C H}_{\mathbf{3}} \mathbf{N H}_{\mathbf{2}} \\
\text { concentration } \\
\left(\mathbf{m g ~ L}^{\mathbf{- 1}}\right)\end{array}$ & $\begin{array}{c}\mathbf{S O}_{\mathbf{4}}{ }^{-2} \\
\text { concentration } \\
\text { (mg L }^{-1} \text { ) }\end{array}$ \\
\hline I & - & - \\
II & - & 1269 \\
III & 1550 & - \\
IV (a) & 1550 & 2183 \\
IV (b) & 1550 & 1230 \\
IV (c) & 1550 & 711 \\
\hline
\end{tabular}

Before inoculating the reactors, the sludge was previously washed, fragmented and kept under nitrogen $\left(\mathrm{N}_{2}, 100 \%\right)$ flow. Throughout the experiments, the gas pressure in the headspace of the experimental bottles was not released. Incubation was performed by using a shaker at a stirring speed of 150 rpm and a heater at the temperature of $30 \pm 1^{\circ} \mathrm{C}$.

The composition of the biogas generated through anaerobic degradation of methylamine was monitored by gas chromatography using a Gow-Mac $\AA$ chromatograph with a thermal conductivity detector (TCD) and Porapak® Q $(2 \mathrm{~m} \times 1 / 4 "-80$ a 100 mesh $)$ column. The biogas samples were collected in a glass syringe. Internal pressure was not equalized to atmospheric pressure to obtain total mass values of formed methane (headspace pressures were unknown; concentration of methane was determined, not the percentage of methane in the biogas). The point of maximum methane production rate was obtained by fitting a sigmoidal Boltzmann function to the experimental data (concentration of $\mathrm{CH}_{4}$ as a function of time). The peak was then determined by numerical differentiation of the adjusted equation. The fitting procedure was carried out by using the software Microcal ${ }^{\circledR}$ Origin 6.1 (Levenberg-Marquardt and Savitzky-Golay smoothing algorithm). The maximum 
specific methane production rate was determined from the average mass of biomass in each reactor ( $\mathrm{g}$ of total volatile solids - TVS).

Total ammonium- $\mathrm{N}\left(\mathrm{NH}_{4}{ }^{+}-\mathrm{N}\right)$, sulfate $\left(\mathrm{SO}_{4}{ }^{2-}\right)$, sulfide $\left(\mathrm{S}^{2-}\right)$ and TVS concentrations were quantified according to the Standard Methods for the Examination of Water and Wastewater (2005).

The microbial community present in the anaerobic batch reactors was analyzed by partial sequencing of the 16 subunit ribosomal RNA gene (16S rRNA). The total genomic DNA was extracted according to Melvin and Hobson (1994). For the Polymerase Chain Reaction (PCR), universal primers for Bacteria domain 27F and 1100R were used (Lane, 1991). The PCR products were purified with Illustra ${ }^{\circledR}$ GFX ${ }^{\circledR}$ kit (GE Healthcare $\left.{ }^{\circledR}\right)$. Cloning was performed with pGEM ${ }^{\circledR}$ Easy Vector System I, according to the manufacturer's specifications. Samples were sequenced in the automatic sequencer ABI Prism ${ }^{\circledR} 310$ (Applied Biosystem ${ }^{\circledR}$ ). The sequences obtained were verified with the software DNAstar ${ }^{\circledR} \quad$ (Lasergene ${ }^{\circledR}$ Sequence Analysis), aligned within the Greengenes NAST aligner (http://greengenes.lbl.gov/cgi-bin/nph-NAST_align.cgi) and phylogenetically analyzed with the software ARB (Ludwig et al., 2004).

\section{RESULTS AND DISCUSSION}

With respect to the control experiments, the methane concentrations were higher in the methylamine- and sulfate-free tests $\left(\sim 6 \mathrm{mmol} \mathrm{CH}_{4} \mathrm{~L}^{-1}\right.$; Figure 1(a)) compared to the methylamine-free and sulfate-containing reactors $\left(\sim 2 \mathrm{mmol} \mathrm{CH}_{4} \mathrm{~L}^{-1}\right.$; Figure 1(b)). This was anticipated because it is well established that sulfate, when present in anaerobic media, creates a competition for substrate by acting as the final electron acceptor in the anaerobic respiration reaction.

The highest headspace concentrations of $\mathrm{CH}_{4}$ and $\mathrm{CO}_{2}$ were of the same order of magnitude in the reactors that received methylamine as carbon source, regardless of the presence of sulfate and its concentration. The concentrations of $\mathrm{CH}_{4}$ and $\mathrm{CO}_{2}$ were approximately 36 and $8 \mathrm{mmol} \mathrm{L}^{-1}$, respectively (Figure 2 (a), 2 (b), 2 (c) and 2 (d)) in the reactors containing methylamine (with or without sulfate). Unlike the control cases (Figures 1 (a) and 1 (b)), the addition of sulfate in the process did not affect the highest produced methane concentration when methylamine was used as the sole carbon source. This indicates that methane-producing organisms and sulfate-utilizing organisms do not compete for methylamine, which is quite interesting because it makes anaerobic digestion of methylamine even more robust.

The maximum methane production rates were $13.16 \pm 0.61,13.41 \pm 1.80,11.65 \pm 0.44$ and $14.24 \pm 0.028$ mmol CH$~_{4} \mathrm{~L}^{-1}$ day $^{-1}$ for the control (with methylamine and without sulfate) and for methylamine/sulfate ratios of $0.71,1.26$ and 2.18, respectively (Table 2). For these ratios, maximum specific methane production rates were $2.14 \pm 0.31,2.41 \pm 0.27,2.26 \pm 0.25$ and $2.54 \pm 0.10 \mathrm{mmol} \mathrm{CH}_{4} \mathrm{~L}^{-1} \mathrm{~g} \mathrm{TVS}^{-1}$ day ${ }^{-1}$, respectively (Table 2). These results were not statistically significantly different from each other (ANOVA: $\mathrm{p}=0.46, \mathrm{~F}=0.98$; Fcrit $=4.76$ ).

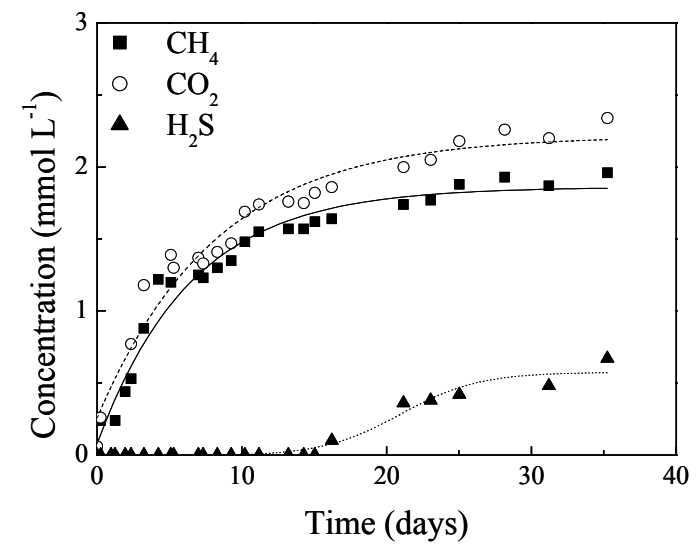

(b)

(a)

Figure 1: Concentration of $\mathrm{CH}_{4}, \mathrm{CO}_{2}$ and $\mathrm{H}_{2} \mathrm{~S}\left(\mathrm{mmol} \mathrm{L}^{-1}\right.$ ) over time (days) in the control reactor (a) without methylamine and sulfate; (b) without methylamine and with $1230 \mathrm{mg} \mathrm{L}^{-1}$ of sulfate): ( $\left.\mathbf{\square}, \circ, \mathbf{\Lambda}\right)$ experimental data; (一, ----, ---) data for $\mathrm{CH}_{4}, \mathrm{CO}_{2}$ and $\mathrm{H}_{2} \mathrm{~S}$ production fit by the Boltzmann model. 


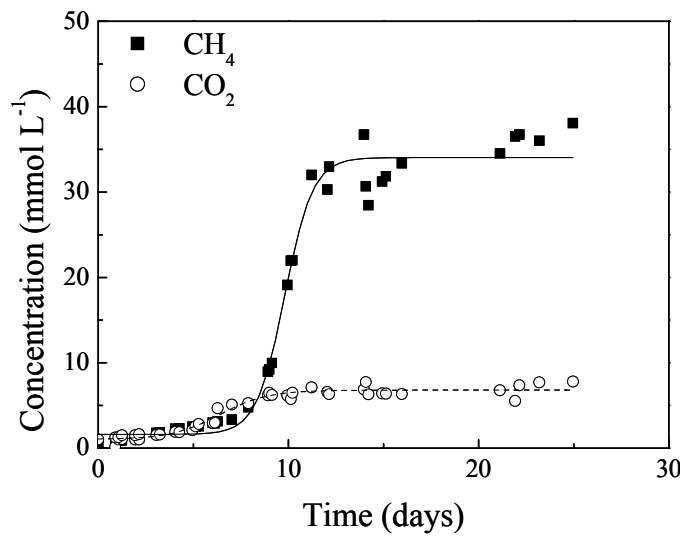

(a)

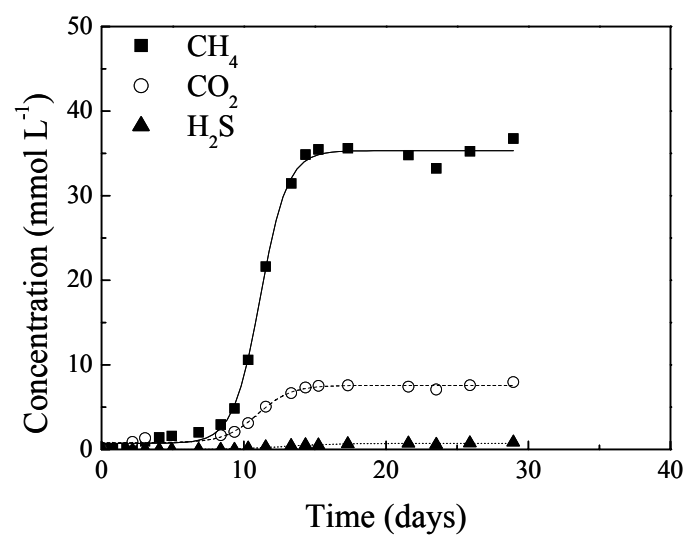

(c)

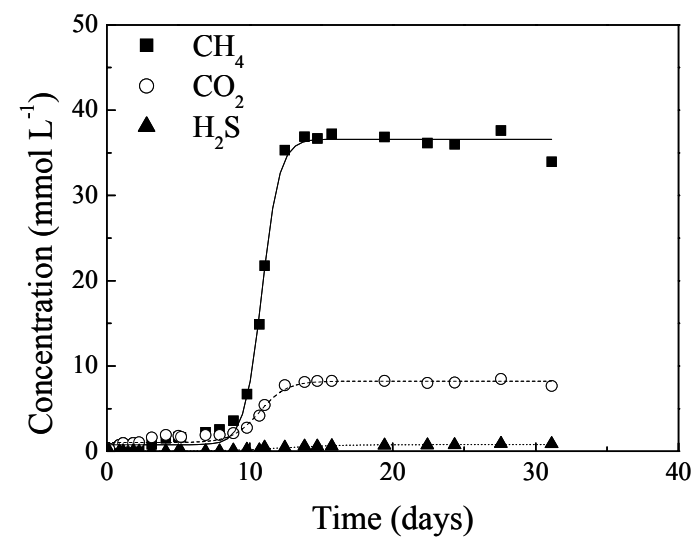

(b)

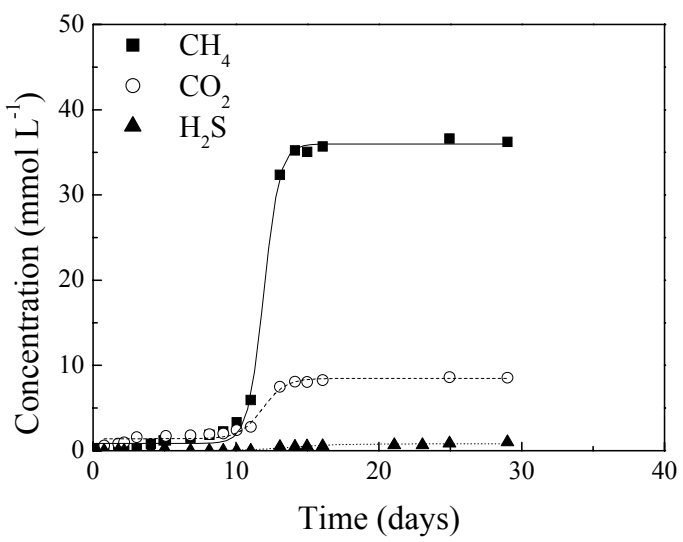

(d)

Figure 2: Concentration of $\mathrm{CH}_{4}, \mathrm{CO}_{2}$ and $\mathrm{H}_{2} \mathrm{~S}\left(\mathrm{mmol} \mathrm{L}{ }^{-1}\right)$ over time (days) in the control reactor with methylamine only (a) and in the reactors with different methylamine/sulfate ratios (b) 0.71 ; (c) 1.26 and (d) 2.18 ): ( $\mathbf{\square}, 0, \mathbf{\Delta})$ experimental data; (-, ----, ----) data for $\mathrm{CH}_{4}, \mathrm{CO}_{2}$ and $\mathrm{H}_{2} \mathrm{~S}$ production fit by the Boltzmann model.

Table 2: Methane production rates and total volatile solids concentration

\begin{tabular}{|c|c|c|c|}
\hline Experimental condition & $\begin{array}{c}\mathrm{MPR}_{\mathrm{CH} 4} \\
\left(\mathrm{mmol} \mathrm{L}^{-1} \mathrm{dia}^{-1}\right)\end{array}$ & $\begin{array}{c}\text { MSPR }_{\mathrm{CH} 4} \\
\left(\mathrm{mmol} \mathrm{L}^{-1} \mathrm{~g} \mathrm{TVS}^{-1} \mathrm{day}^{-1}\right)\end{array}$ & $\begin{array}{l}\text { TVS } \\
\left(\mathrm{g} \mathrm{L}^{-1}\right)\end{array}$ \\
\hline I & $0.21 \pm 0.0017$ & $0.045 \pm 0.0022$ & 4.63 \\
\hline II & $0.26 \pm 0.0037$ & $0.05 \pm 0.0042$ & 4.92 \\
\hline III & $13.16 \pm 0.61$ & $2.14 \pm 0.31$ & 6.19 \\
\hline IV (a) & $13.41 \pm 1.80$ & $2.41 \pm 0.28$ & 5.28 \\
\hline IV (b) & $11.65 \pm 0.44$ & $2.26 \pm 0.25$ & 5.12 \\
\hline IV (c) & $14.24 \pm 0.028$ & $2.54 \pm 0.14$ & 5.31 \\
\hline
\end{tabular}

Legend: $\mathrm{MPR}_{\mathrm{CH} 4}$ - maximum methane production rate; $\mathrm{MSPR}_{\mathrm{CH} 4}$ - maximum specific methane production rate;

TVS - total volatile solids; values represent mean and standard deviation.

The $\mathrm{pH}$ decreased significantly during the tests at the different methylamines/sulfate ratios (Table 3). Due to the addition of methylamine (electron donor), the $\mathrm{CO}_{2}$ concentrations, $\sim 8 \mathrm{mmol} \mathrm{L}^{-1}$ (Figures 2 (a), 2 (b), 2 (c) and 2 (d)), were higher than the $\mathrm{CO}_{2}$ concentrations in the control, $\sim 2 \mathrm{mmol} \mathrm{L}^{-1}$ (without addition of methylamine) (Figures 1 (a) and 1 (b)). The accumulation of $\mathrm{CO}_{2}$ in the tests was responsible for the further decrease of $\mathrm{pH}$. Because the production of biogas in the control reactor was lower, the final $\mathrm{pH}$ value was not as low as the values obtained in the other reactors (Table 3 ). The addition of sulfate contributed to the maintenance of $\mathrm{pH}$, since it is biologically converted to $\mathrm{S}^{-2}$ and, consequently, other forms such as $\mathrm{HS}^{-}$and $\mathrm{H}_{2} \mathrm{~S}$ are formed. A simplified analysis, considering only sulfide aquatic chemistry, can be made to predict the theoretical $\mathrm{pH}$ in the reactors containing 
methylamine and sulfate (data: TOT- $\mathrm{S}^{-2}=\left[\mathrm{H}_{2} \mathrm{~S}\right]+\left[\mathrm{HS}^{-}\right]$ $+\left[\mathrm{S}^{2-}\right] ; \mathrm{pK}_{\mathrm{a} 1}=6.99$ and $\mathrm{pK}_{\mathrm{a} 2}=12.92 ; \mathrm{H}_{\mathrm{H} 2 \mathrm{~S}}=0.4 \mathrm{~L} / \mathrm{L}$; TOT-S $^{-2}=0.00469 \mathrm{~mol} \mathrm{~L}^{-1}$ [Figure $\left.3(\mathrm{~b})\right] ;\left[\mathrm{H}_{2} \mathrm{~S}\right]_{\mathrm{aq}}=$ $0.0025 \mathrm{~mol} \mathrm{~L}^{-1}$ [Figure 2 (b), 2 (c), and 2 (d)]). The theoretical $\mathrm{pH}$ was found to be 6.94 , while the measured $\mathrm{pH}$ was $\sim 7.14$ (Table 3 ). Even though the theoretical and measured $\mathrm{pH}$ values are similar, the biological phenomena involved in determining the final measured $\mathrm{pH}$ are too complex. If we consider $\mathrm{CO}_{2}$ formation and its aqueous chemistry, the theoretical $\mathrm{pH}$ could be even lower than the predicted one. This is balanced out by the added buffer compounds and others, such as ammonia, that are produced during the biological reactions.

Total ammonium-N (Figure 4) and sulfide (Figure 3 (b)) were produced during the experiment. The final concentration of total ammonium- $\mathrm{N}$ was around 1100 mg $\mathrm{NH}_{4}^{+}-\mathrm{N} \mathrm{L}^{-1}$ for all methylamine/sulfate ratios, substantiating the process represented by reaction 1 . Control reactors (without methylamine as a source of $\mathrm{C}$ and $\mathrm{N}$ ) had a concentration of ammonium of $\sim 300 \mathrm{mg}$ $\mathrm{NH}_{4}^{+}-\mathrm{N} \mathrm{L}^{-1}$.

Table 3: Initial and final $\mathrm{pH}$ for the different methylamine/sulfate ratios

\begin{tabular}{|c|c|c|c|c|}
\hline & $\begin{array}{c}\text { Control } \\
\text { (no methylamine) }\end{array}$ & $\mathbf{0 . 7 1}$ & $\mathbf{1 . 2 6}$ & $\mathbf{2 . 1 8}$ \\
\hline Initial pH & $8.92 \pm 0.08$ & $8.92 \pm 0.07$ & $8.97 \pm 0.02$ & $8.94 \pm 0.13$ \\
Final pH & $7.67 \pm 0.09$ & $7.08 \pm 0.04$ & $7.14 \pm 0.04$ & $7.19 \pm 0.05$ \\
\hline
\end{tabular}

Values represent mean and standard deviation.

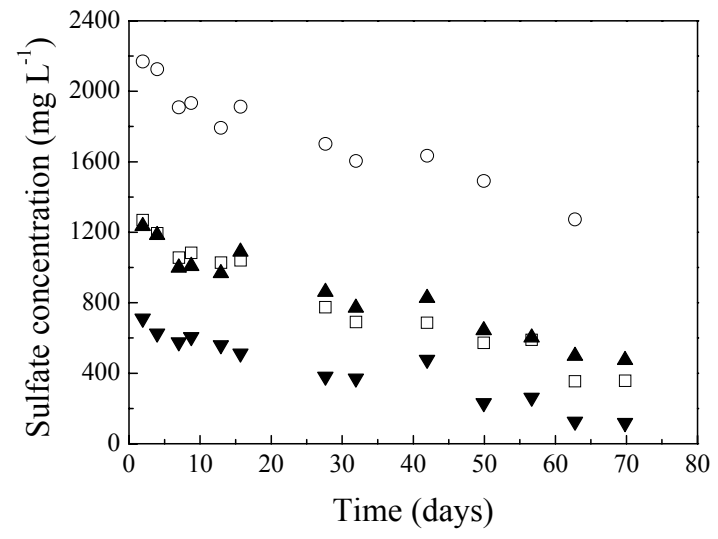

(a)

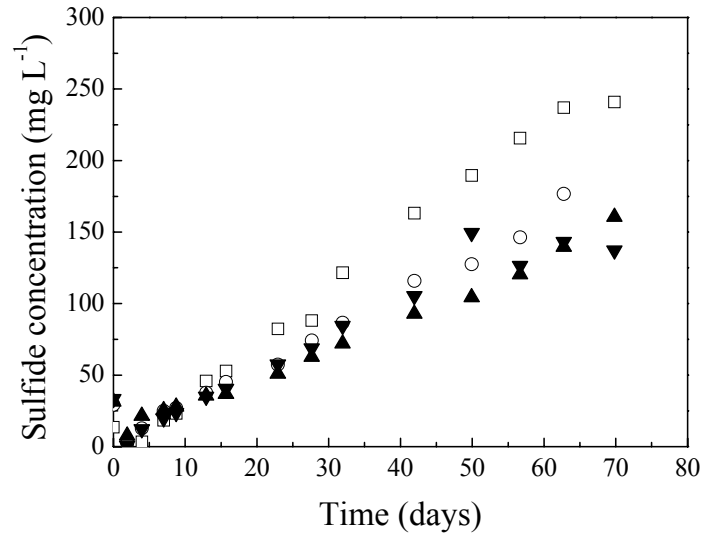

(b)

Figure 3: Concentration of sulfate (a) and sulfide (b) over time in the anaerobic batch reactors: $\square-$ control (without methylamine and with sulfate); $\circ-0.71 ; \mathbf{\Delta}-1.26$ e $\mathbf{\nabla}-2.18$.

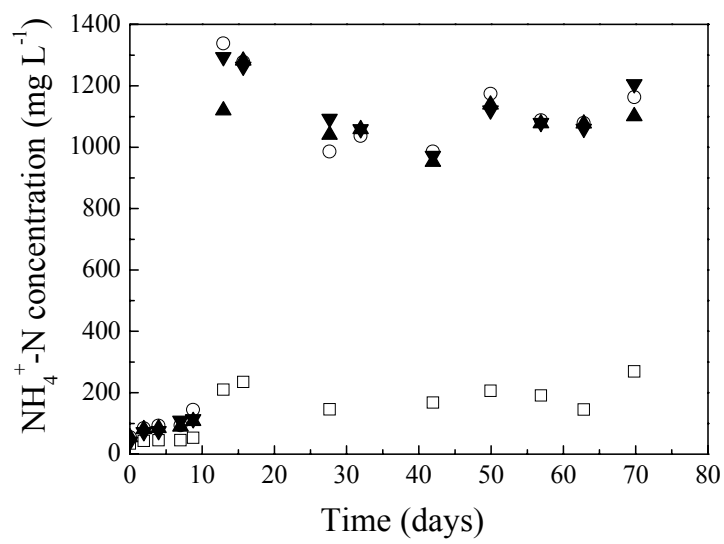

Figure 4: Concentration of ammonium over time in the anaerobic batch reactors: $\square-$ control (without methylamine and with sulfate); $\circ-0.71 ; \Delta-1.26$ e $\nabla-2.18$. 
Sulfide concentrations values were about $150 \mathrm{mg} \mathrm{L}^{-1}$ in the reactors subjected to different sulfate concentrations, regardless of the methylamine/sulfate ratio. Control reactors (without methylamine and with sulfate) achieved an average sulfide concentration of $241 \mathrm{mg} \mathrm{L}^{-1}$ (Figure 3 (b)). According to these results, it is possible to infer that methanogenesis was favored by the addition of methylamine and that a negative effect on sulfidogenesis occurred, possibly due to methylamine inhibition of sulfate-consuming microorganisms and/or scavenging of free protons $\left(\mathrm{H}^{+}\right)$ to form ammonium and methane by acetoclastic methanogens.

The control reactors with sulfate (without methylamine) consumed $71.9 \%$ of the added sulfate (1269 mg L $\mathrm{m}^{-1}$ ). The reactors with methylamine/sulfate ratios of $0.71,1.26$ and 2.18 consumed $41.3 \%, 61.6 \%$ and $83.2 \%$ of all the sulfate added, for sulfate concentrations of 2183,1230 and $711 \mathrm{mg} \mathrm{L}^{-1}$, respectively (Figure 3 (a)). These percentages reveal greater efficiencies of consumption of sulfate when it is present at lower concentrations.

The microscopic analysis confirmed the similarity of the morphologies that are expected to be present in the reactors containing methylamine (Vich, 2006).

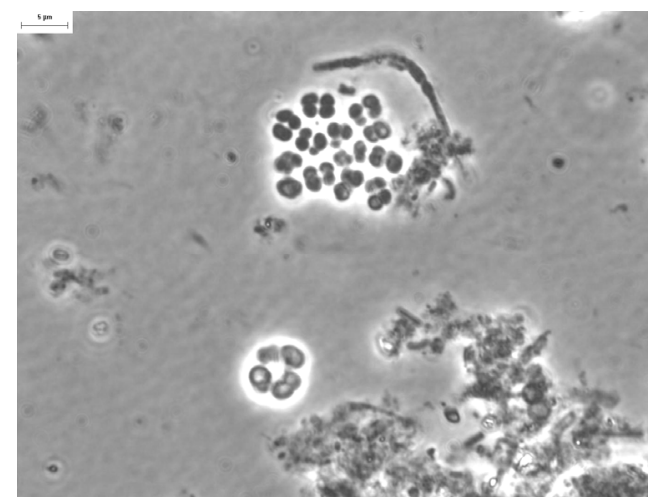

(a)

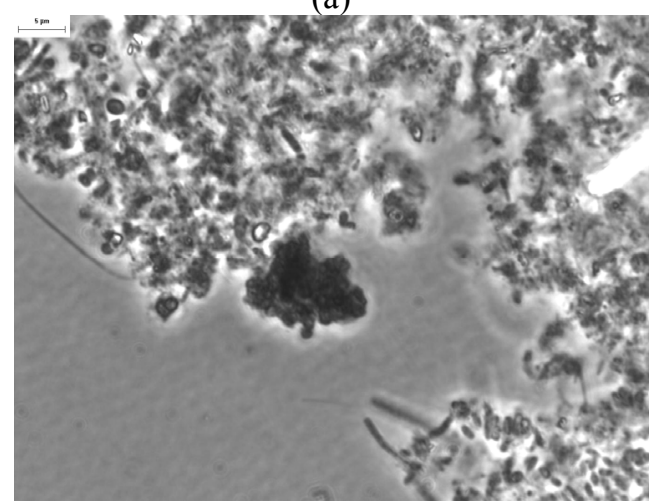

(c)
Microorganisms similar to those belonging to the Methanosarcinales family were the representative ones for the Archaea domain (Figure 5(c)). The Bacteria domain was represented by rods and coccirods (Figure 5 (b)), cocci (Figure 5(a)), and filaments (Figure $5(\mathrm{~d})$ ).

For the control reactors fed with methylamine and without addition of sulfate, the microbial community structure related to the Bacteria domain was mainly represented by the phyla Spirochaetes (40\%), Deferribacteres (17\%) and Bacteroidetes (16\%) (Figure 6 (a)). The phyla Firmicutes (46\%), Deferribacteres (13\%) and Proteobacteria (12\%) were predominant in the reactor containing methylamine and sulfate at the ratio of 1.26 (Figure 6 (b)). Despite this shift of populations in the bacterial community that resulted from the addition of sulfate, methane production did not change in the tests with addition of sulfate. It should be pointed out that the phylum Proteobacteria was enriched by sulfate addition (from 5 to $12 \%$ ), which is in agreement with the literature (Hanson and Hanson, 1996; Kalyuzhnaya et al., 2006); the Proteobacteria phylum contains species capable of converting methylotrophic substrates.

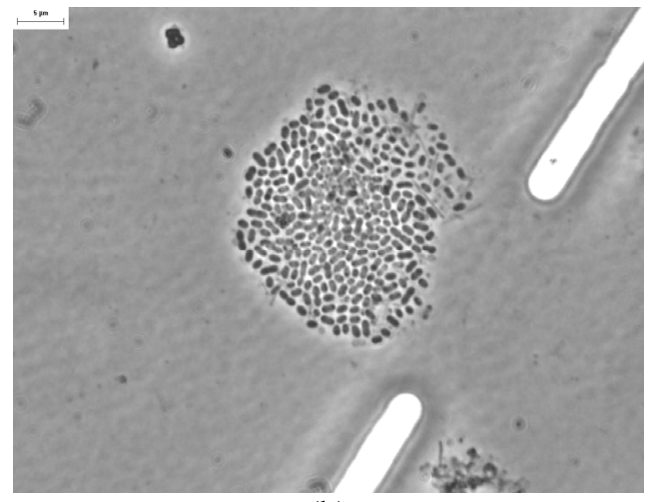

(b)

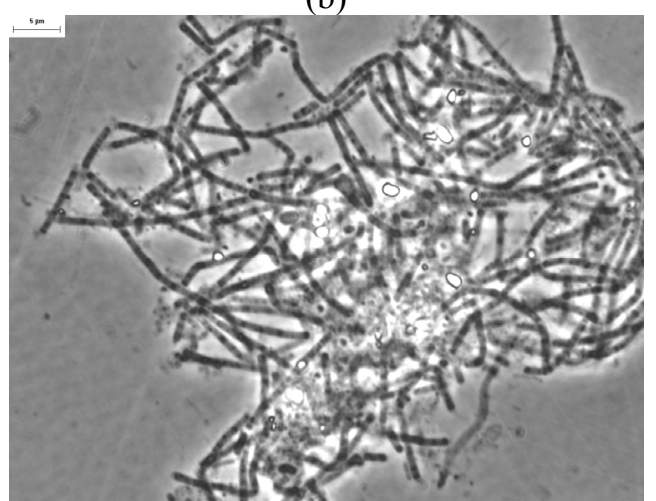

(d)

Figure 5: Phase contrast microscopy of the anaerobic batch reactor biomass (methylamine/sulfate ratio of 1.26): (a) cocci cells; (b) rod, cocci-rod cells; (c) sarcina-like cells; (d) filament cells. 


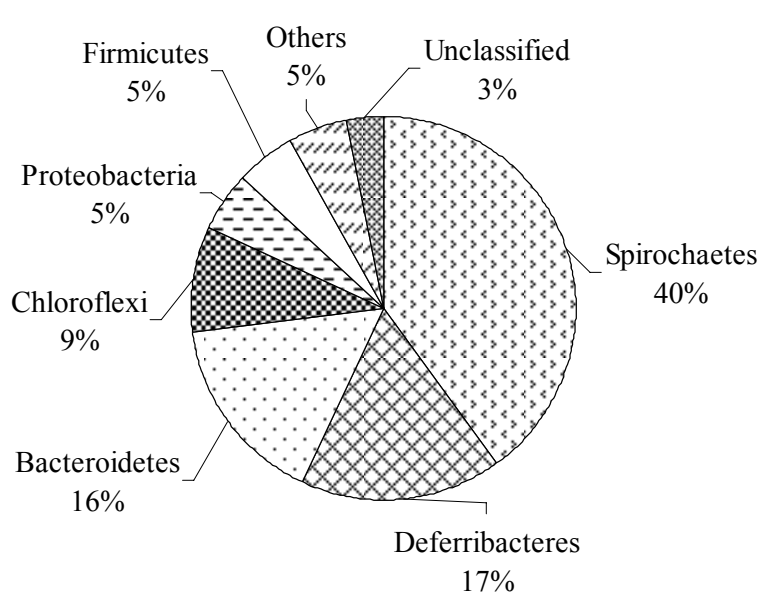

(a)

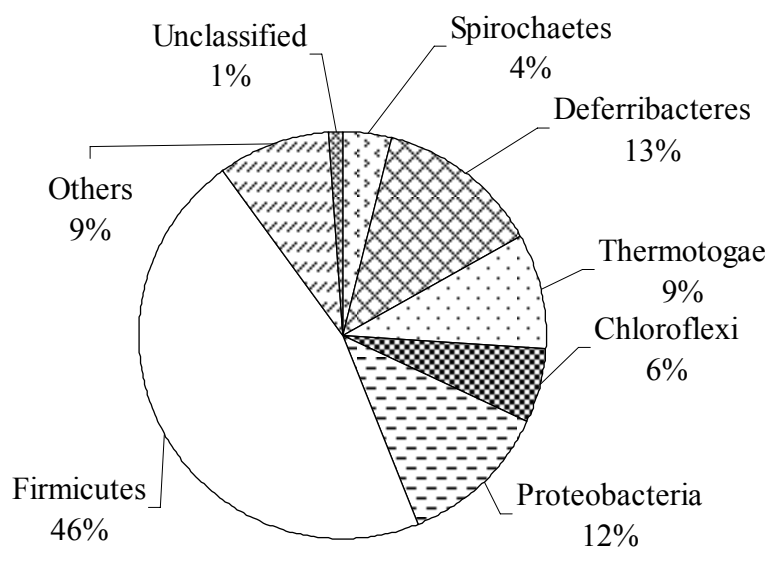

(b)

Figure 6: Bacterial community structure in the control reactor with methylamine and without sulfate (a) and in the reactor with a methylamine/sulfate ratio of 1.26 (b).

Sarti (2007) analysed the granular sludge used in our work by the Fluorescent in situ Hybridization (FISH) technique. The sludge was sampled from an Upflow Anaerobic Sludge Blanket (UASB) reactor treating poultry wastes (Dacar, Tietê, SP, Brazil), which contained sulfate (there is no information on the presence of methylamine in this digester). The microbial population distribution within a biomass sample was $49.8 \%, 56.7 \%$ and $27.9 \%$ for the FISH probes EUB338 (Bacteria), ARC915 (Archaea) and BRS385 (sulfate-consuming bacteria), respectively. These percentages represent a sludge with high methanogenic potential and it might have facilitated methylamine removal from the media, as the methane production seems to be driven predominantly by methanogenic activity because: i. the bacterial community changed, but the methane production did not; ii. total ammonium- $\mathrm{N}$ and methane formation obeyed methanogenic stoichiometric levels (reaction 1). For instance, the theoretical methane and total ammonium-N concentrations formed from methylamine consumption at a concentration of 1550 $\mathrm{mg} \mathrm{L}^{-1}$ (1-L reaction and headspace volumes) are approximately $37 \mathrm{mmol} \mathrm{L}^{-1}$ and $700 \mathrm{mg} \mathrm{N} \mathrm{L}^{-1}$, respectively. We found methane and total ammonium$\mathrm{N}$ production values of $\sim 36 \mathrm{mmol} / \mathrm{L}$ (Figures 2 (a), 2 (b), 2 (c), and 2 (d)) and $~ 800 \mathrm{mg} \mathrm{N} \mathrm{L}^{-1}$ (Figure 4) (difference between experimental conditions II and IV [(a), (b), and (c),]), respectively. If methylamineconsuming bacterial activity were high, which might have been the case if a much longer adaptation time had been allowed, it is likely that methane formation would decrease with increasing sulfate concentrations.

\section{CONCLUSIONS}

The addition of sulfate inhibited the production of methane only in the control reactors without addition of methylamine. In the presence of methylamine, the addition of different concentrations of sulfate did not influence the production of methane, even though the bacterial community structures were altered, indicating that methanogenic archaea and sulfatereducing bacteria did not compete for this source of carbon and that bacterial methylamine degradation does not occur to a significant extent.

\section{REFERENCES}

APHA-AWWA-WPCF, Standard Methods for the Examination of Water and Wastewater. 20th ed. American Public Health Association/American Water Works Association/Water Environment Federation, Washington, DC, USA (2005).

Deppenmeier, U., Lienard, T., Gottschalk, G., Novel Reactions Involved in Energy Conservation by Methanogenic Archaea. FEBS Letters, 457, 291297 (1999).

Hanson, R. S., Hanson, T. E., Methanotrophic Bacteria. Microbiological Reviews, 60, 437-471 (1996).

Kalyuzhnaya, M. G., Bowerman, S., Lara, J. C., Lidstrom, M. E. \& Chistoserdova, L., Methylotenera Mobilis gen. nov., sp. nov, an Obligately Methylamine-Utilizing Bacterium Within the Family Methylophilaceae. International Journal of 
Systematic and Evolutionary Microbiology, 56, 2819-2823 (2006).

Kalyuzhnaya, M. G., Lapidus, A., Ivanova, N., Copeland, A. C., McHardy, A. C., Szeto, E., Salamov, A., Grigoriev, I. V., Suciu, D., Levine, S. R., Markowitz, V. M., Rigoutso, I., Tringe, S. G., Bruce, D. C., Richardson, P. M., Lidstrom, M. E., Chistoserdova, L., High-Resolution Metagenomics Targets Specific Functional Types in Complex Microbial Communities. Nature Biotechnology, 26, no. 9, 1029-1034 (2008).

Lane, D. J., 16S/23S rRNA Sequencing in Nucleic Acid Techniques. John Wiley and Sons Inc., New York (1991).

Ludwig, W., Strunk, O., Westram, R., Richter, L., Meier, H., Yadhukumar, A.,Buchner, T., Lai, S., Steppi, G., Jobb, G., ARB: A Software Environment for Sequence Data. Nucleic Acids Research, 32, 1363-1371 (2004).

Melvin, A. N. W. T., Hobson, P. P., Identification of Anaerobic Digester Bacteria Using Polimerase Chain Reaction Method. Bioresource Technology, 47, 73-80 (1994).

Sarti, E. L., Oxygen Influence on Methanogenic Archaea and Sulfate Reducing Bacteria's Growth in Anaerobic Batch Reactors. M.Sc. Thesis, University of São Paulo (2007).

Sossa, K., Alarcón, M., Aspé, E., Urrutia, H., Effect of Ammonia on the Methanogenic Activity of Methylaminotrophic Methane Producing Archaea Enriched Biofilm. Anaerobe, 10, 13-18 (2004).

Thauer, R. K., Biochemistry of Methanogenesis: a Tribute to Marjory Stephenson: 1998 Marjory Stephenson Prize Lecture. Microbiology, 144, 2377-2406 (1998).

Touzel, J. P., Albagnac, G., Isolation and Characterization of Methanococcus mazei Strain MC3. FEMS Microbiology Letters, 16, 241-245 (1983).

Vich, D.V., Methanogenic Activity and Microbial Community Involved in the Degradation of Methylamine. M.Sc. Thesis, University of São Paulo (2006).

Yaws, C. L., Matheson Gas Data Book. 7th Ed. McGraw-Hill, New York (2001).

Zinder, S. H., Cardwell, S. C., Anguish, T., Lee, M., Koch, M., Methanogenesis in a Thermophilic $\left(58^{\circ} \mathrm{C}\right)$ Anaerobic Digestor. Methanothrix sp. as an Important Acetoclastic Methanogen. Applied and Environmental Microbiology, 47, 96-807 (1984). 